\title{
PENERAPAN MODEL KOOPERATIF LEARNING TIPE THINK PAIR SHARE (TPS) UNTUK MENINGKATKAN AKTIVITAS DAN HASIL BELAJAR KIMIA SISWA KELAS X PADA MATERI REAKSI REDOKS TP. 2017/2018
}

\author{
YULIANA \\ Guru SMA N 2 Rambah Hilir Rokan Hulu
}

\begin{abstract}
ABSTRAK
Tujuan penelitian ini adalah melalui penerapan model kooperatif learning tipe Think Pair Share dapat meningkatkan aktivitas dan hasil belajar siswa pada pokok bahasan reaksi redoks. Penelitian tindakan kelas ini dilaksanakan dalam bentuk proses pengkajian bersiklus yang terdiri dari 4 tahapan. Tahapan tersebut adalah perencanaan, tindakan, observasi, dan refleksi. Dengan menggunakan model pembelajaran kooperatif tipe TPS dapat meningkatkan aktivitas dan hasil belajar kimia pada pokok bahasan reaksi redoks pada siswa kelas X.MIA 1 semester 2 SMA N 2 Rambah Hilir Tahun ajaran 2017/2018. Hal ini ditunjukkan adanya perubahan sikap siswa dalam pembelajaran, diantaranya adalah interaksi dan kerja sama antar siswa semakin baik, siswa semakin mempunyai keberanian untuk mengemukakan ide dan pendapat di depan kelas. Pusat pembelajaran tidak lagi pada guru. Siswa dituntut untuk aktif mencari informasi serta harus dapat saling bertukar pikiran. Peningkatan ini terlihat dari nilai rata-rata yang diperoleh siswa yaitu 78,33 pada siklus 1 , kemudian meningkat menjadi 82,50 pada siklus 2. Ketuntasan belajar siswa juga mengalami peningkatan pada siklus 1 adalah 63,33\%, kemudian pada siklus 2 meningkat menjadi 86,67\%. Ketuntasan belajar siswa secara klasikal sudah terpenuhi yaitu $85 \%$ dari jumlah siswa memperoleh nilai lebih besar atau sama dengan 76 . Namun secara individual masih ada 4 siswa yang belum tuntas belajar. Siswa mempunyai kesempatan untuk mempelajari materi secara berulang-ulang dan kemudahan memahami materi yang disampaikan oleh teman sebaya. Siswa dituntut untuk bertukar informasi atau mengajarkan materi kepada temannya sehingga dapat meningkatkan pemahaman dan ingatan siswa pada materi yang dipelajari serta bertanggung jawab pada saat kuis.
\end{abstract}

\section{Kata Kunci: Penelitian Tindakan Kelas, Hasil Belajar, Kooperatif Learning Tipe Think Pair Share}

\section{PENDAHULUAN}

Pendidikan adalah usaha sadar dan terencana untuk mewujudkan pembelajaran, suasana belajar dan proses belajar membantu peserta didik secara aktif mengembangkan potensi dirinya sendiri. Guru merupakan tenaga pendidik yang secara langsung terlibat dalam proses belajar mengajar, maka guru sebagai pendidik memegang peranan penting dalam meningkatkan kualitas sumber daya manusia, guru sebagai ujung tombak peningkatan mutu pendidikan, pengajar maupun pendidik sehingga guru dituntut untuk memiliki berbagai kompetensi yang diperlukan agar materi yang disampaikan dapat diterima dengan baik. Guru menggunakan strategi belajar yang tidak mengharuskan siswa menghafal fakta- fakta tetapi sebuah strategi yang mendorong siswa membangun pengetahuan di benak mereka sendiri. Model pembelajaran yang digunakan guru sangat berpengaruh dalam menciptakan situasi belajar yang benar-benar menyenangkan dan mendukung kelancaran proses belajar mengajar, serta sangat membantu dalam pencapaian hasil belajar yang memuaskan.

Kekurangaktifan siswa yang terlibat dalam proses pembelajaran dapat terjadi karena metode yang digunakan kurang melibatkan aktivitas siswa secara langsung. Pembelajaran di kelas masih banyak didominasi oleh guru sehingga kurang mampu membangun persepsi, minat, dan sikap siswa yang lebih baik. Kebanyakan anak didik mengalami kebosanan dikarenakan model pembelajaran yang berpusat pada guru sehingga kurangnya minat dan sikap siswa tersebut berdampak terhadap hasil belajar yang secara umum kurang memuaskan.

Hasil observasi awal dan diskusi dengan guru kimia SMAN 2 Rambah Hilir diperoleh bahwa hasil belajar kimia siswa kelas X selama 
ini sangat rendah (rata-rata 65,05). Sedangkan hasil post test pada pokok bahasan Perkembangan Konsep Reaksi ReduksiOksidasi Tahun Pelajaran 2017/2018 juga tidak berbeda (yaitu 72,50), meskipun telah dilakukan berbagai upaya yang dilakukan oleh guru untuk meningkatkan hasil belajar siswa, namun hasilnya masih jauh dari harapan. Rendahnya hasil belajar siswa tersebut diduga kuat akibat motivasi, minat dan aktivitas siswa dalam proses pembelajaran sangat rendah, sehingga terlihat siswa tidak pernah siap untuk menerima materi pelajaran dalam setiap pertemuan. Selain itu, pelajaran kimia baru didapat di SMA sehingga cukup sulit untuk memahami materi yang diajarkan.

Berdasarkan permasalahan yang ada, maka guru sebagai peneliti merasa perlu untuk mengadakan penelitian terhadap strategi pembelajaran berkaitan dengan model pembelajaran yang digunakan oleh guru. Dalam hal ini, peneliti ingin menerapkan model pembelajaran kooperatif TPS (Think Pair Share). Berdasarkan Pembelajaran Kooperatif, peneliti ingin mengembangkan model TPS untuk meningkatkan penguasaan materi dan keaktifan siswa dalam proses pembelajaran yang akan berpengaruh pada hasil belajar siswa dalam mengolah, mencari, dan mendiskusikan dengan teman dalam kelompok kecil. Diskusi dalam bentuk kelompok-kelompok kecil ini sangat efektif untuk memudahkan siswa dalam memahami materi dan memecahkan suatu permasalahan. Dengan cara seperti ini, siswa diharapkan mampu bekerjasama, saling membutuhkan, dan saling bergantung pada kelompok-kelompok kecil secara kooperatif.

\section{Rumusan Masalah}

Perumusan masalah pada penelitian ini adalah: "Apakah penerapan model kooperatif learning tipe Think Pair Share (TPS) dapat meningkatkan aktivitas dan hasil belajar siswa pada pokok bahasan reaksi redoks?

\section{Tujuan Penelitian}

Adapun tujuan penelitian ini adalah melalui penerapan model kooperatif learning tipe Think Pair Share dapat meningkatkan aktivitas dan hasil belajar siswa pada pokok bahasan reaksi redoks. Serta memberikan informasi tambahan kepada guru lain, pihak sekolah dan pihak lainnya.

\section{TINJAUAN PUSTAKA Model Pembelajaran Kooperatif TPS (Think Pair Share)}

Salah satu model pembelajaran kooperatif adalah TPS (Think-Pair-Share) adalah sebuah strategi yang menumbuhkan partisipasi siswa di kelas. Siswa diajarkan menggunakan responsnya untuk menjawab pertanyaan.

Komponen-komponen TPS (Think-Pair-Share):

1. Siswa mendengarkan ketika guru memberi pertanyaan.

2. Siswa diberi waktu berpikir untuk menjawab

3. Siswa kadang-kadang member isyarat untuk berpasangan dengan teman sebangkunya dan berdiskusi menjawab pertanyaan.

4. Akhirnya, siswa berbagi jawaban di grupnya.

Manfaat TPS (Think-Pair-Share) bagi siswa adalah siswa mempunyai waktu berpikir sendiri menjawab pertanyaan sebelum pertanyaan dijawab dan didiskusikan di depan kelas. Mereka berlatih mental untuk menjawab dan kadang-kadang berdebat dengan siswa lainnya. Sebelum di presentasikan di depan kelas. Semua siswa mempunyai kesempatan berbagi pikiran dengan siswa lainnya, dengan demikian menambah pengetahuannya.TPS (Think-Pair-Share) adalah model pembelajaran kooperatif dan manfaat untuk siswa seperti dalam menerima kompetensi yang berkaitan dengan, dukungan kerabat, prestasi, penghargaan diri. Model pembelajaran kooperatif memiliki efek yang positif.

Model pembelajaran tipe Think-PairShare ini dikembangkan oleh Frank Lyman dan kawan-kawan dari Universitas Maryland yang mampu mengubah asumsi bahwa resitas dan diskusi perlu diselenggarakan dalam setting kelas secara keseluruhan. Pembelajaran ThinkPair-Share mempunyai struktur yang sederhana sebagai salah satu dasar dari perkembangan "kelas kooperatif". Model Think-Pair-Share memberi waktu kepada para siswa untuk berfikir dan merespons serta saling membantu yang lain (Triyanto 2007: 61). Sebagai contoh, seorang guru memberikan latihan soal pada 
siswa. Selanjutnya, guru meminta para siswa untuk memikirkan secara lebih serius mengenai soal-soal tersebut. Kemudian, siswa diajak untuk mendiskusikan jawaban soal teesebut sewcara berpasangan. Dari hasil diskusi dengan pasangannya akan diperoleh suatu kesimpulan yang akan dikemukakan dan didiskusikan kembali dengan kelompok yang lebih besar (dalam hal ini adalah teman-teman dalam 1 kelas). Pelaksanaan pembelajaran Think-PairShare memiliki langkah-langkah yang sederhana. Meskipun demikian langkah sederhana tersebut harus diperhatikan terutama menghindari kesalahan dalam kerja kelompok.

Langkah-langkah dalam Model Think-PairShare dapat dijabarkan sebagai berikut:

- Langkah 1 : Guru menyampaikan pertanyaan.

Aktivitas : Guru melakukan apersepsi menjelaskan tujuan pembelajaran dan menyampaikan pertanyaan yang berhubungan dengan kompetensi yang berkaitan dengan yang disampaikan.

- Langkah 2 : Siswa berpikir secara individual.

Aktivitas : Guru memberikan kesempatan kepada para siswa untuk memikirkan jawaban dari permasalahan yang disampaikan oleh guru. Langkah ini dapat dikembangkan dengan meminta siswa untuk menuliskan hasil pemikiran masing-masing.

Tabel 1. Sintaks Model Pembelajaran TPS (Think Pair Share)

\begin{tabular}{|l|l|}
\hline $\begin{array}{l}\text { Fase 1: Menyampaikan tujuan } \\
\text { dan memotivasi siswa }\end{array}$ & $\begin{array}{l}\text { Guru menyampaikan semua tujuan pembelajaran yang ingin } \\
\text { dicapai pada pembelajaran tersebut dan memotivasi siswa. }\end{array}$ \\
\hline $\begin{array}{l}\text { Fase 2: Mengajukan } \\
\text { permasalahan Thinking } \\
\text { (Berpikir) }\end{array}$ & $\begin{array}{l}\text { Guru mengajukan pertanyaan atau isu yang berhubungan } \\
\text { dengan pembelajaran, kemudian siswa diminta untuk } \\
\text { memikirkan pertanyaan atau isu tersebut secara mandiri untuk } \\
\text { beberapa saat. }\end{array}$ \\
\hline $\begin{array}{l}\text { Fase 3: Mengorganisasikan } \\
\text { siswa dalam tim belajar Pairing } \\
\text { (Berpasangan) }\end{array}$ & $\begin{array}{l}\text { Guru meminta siswa berpasangan dengan siswa yang lain } \\
\text { untuk mendiskusikan apa yang telah dipikirkanya pada tahap } \\
\text { pertama. Interaksi pada tahap ini diharapkan dapat berbagi } \\
\text { jawaban jika telah diajukan pertanyaan atau berbagi ide jika } \\
\text { suatu persoalan khusus telah diidentifikasi. }\end{array}$ \\
\hline $\begin{array}{l}\text { Fase 4: Berbagi dengan seluruh } \\
\text { siswa Sharing (Berbagi) }\end{array}$ & $\begin{array}{l}\text { Pada tahap akhir, guru meminta kepada pasangan untuk } \\
\text { berbagi dengan seluruh kelas tentang apa yang telah mereka } \\
\text { bicarakan. Ini efektif dilakukan dengan cara bergiliran } \\
\text { pasangan demi pasangan dan dilanjutkan sampai sekitar } \\
\text { seperempat pasangan telah mendapat kesempatan untuk } \\
\text { melaporkan. }\end{array}$ \\
\hline Fase 5: Melakukan evaluasi & \begin{tabular}{l} 
Guru mengevaluasi hasil belajar tentang materi yang telah \\
\hline
\end{tabular} \\
\hline
\end{tabular}

- Langkah 3 : Setiap siswa mendiskusikan hasil pemikiran masing-masing dengan pasangannya.

Aktivitas : Guru mengorganisasikan siswa untuk berpasangan dan memberi kesempatan untuk mendiskusikan jawaban yang menurut mereka paling benar atau paling meyakinkan. Guru memberikan motivasi kepada siswa untuk aktif dalam kerja kelompok.

- Langkah 4 : Siswa berbagi jawaban mereka pada seluruh kelas

Aktivitas : Siswa mempresentasikan jawaban atau pemecahan masalah secara individu dan kelompok di depan kelas.

- Langkah 5: Menganalisis dan mengevaluasi hasil pemecahan

Aktivitas : Guru membantu siswa untuk melakukan refleksi atau evaluasi terhadap hasil pemecahan masalah yang telah didiskusikan.

- Langkah 6 : Memberi penghargaan

Aktivitas : Guru mencari cara-cara untuk menghargai baik upaya maupun hasil belajar individu dan kelompok. 


\begin{tabular}{|l|l|}
\hline Fase 6: Memberi penghargaan & dipelajari \\
\hline $\begin{array}{l}\text { Guru mencari cara-cara untuk menghargai baik upaya maupun } \\
\text { hasil belajar individu dan kelompok. }\end{array}$ \\
\hline
\end{tabular}

(Sumber: Lie, 2007)

\section{METODOLOGI PENELITIAN}

\section{Tempat dan Waktu Penelitian}

Pelaksanaan penelitian pada semester genap tahun pelajaran 2017/2018 di kelas X SMAN 2 Rambah Hilir. Penelitian dan pelaporan dilaksanakan pada bulan Januari sampai dengan bulan Februari 2018, pelaksanaan tindakan selama 6 jam pelajaran. Tiap jam pelajaran berlangsung selama 45 menit.

\section{Subjek Penelitian}

Penelitian dilaksanakan di SMAN 2 Rambah Hilir kelas X MIA 1 semester genap TP. 2017/2018 dengan jumlah siswa sebanyak 30 orang.

\section{Prosedur Penelitian}

Penelitian tindakan kelas ini dilaksanakan dalam bentuk proses pengkajian bersiklus yang terdiri dari 4 tahapan. Tahapan tersebut adalah perencanaan, tindakan, observasi, dan refleksi.

\section{Siklus 1}

a. Perencanaan

Perencanaan dalam penelitian ini yaitu mencari solusi untuk mengatasi masalah yang timbul berdasarkan observasi awal. Perencanaan yang dilakukan peneliti yaitu:
a) menyusun silabus
b) menyusun rencana pembelajaran
c) menyusun bahan pengajaran yang akan diberikan pada siswa
d) Menyusun Lembar Kerja Siswa (LKS)
e) menyusun soal latihan sesuai dengan model pembelajaran TPS
f) menyusun alat evaluasi
g) menyusun soal
h) menyusun lembar observasi

b. Tindakan

Adapun langkah - langkah pelaksanaan model pembelajaran kooperatif Think-Pair-Share (TPS) pada siklus 1 dan siklus berikutnya secara rinci sebagai berikut:
1) Guru membuka proses belajar mengajar.

2) Guru mempresentasikan model pembelajaran kooperatif Think Pair Share (TPS) kepada siswa.

3) Guru menyampaikan materi pelajaran.

4) Guru mengajukan pertanyaan atau masalah yang berkaitan dengan pelajaran.

5) Guru meminta siswa menggunakan waktu beberapa menit untuk berpikir sendiri jawaban atau masalah.

6) Guru meminta siswa untuk berpasangan dengan teman sebangkunya dan mendiskusikan apa yang telah mereka peroleh selama 4 atau 5 menit.

7) Guru meminta pasangan-pasangan untuk berbagi dengan keseluruhan kelas mengenai permasalahan yang telah didiskusikan.

8) Guru membuat kesimpulan tentang materi yang telah diajarkan dan didiskusikan tadi.

9) Memberikan tes ujian atau kuis yang bersifat individual.

10) Memberikan waktu kepada siswa untuk mengerjakan kuis.

11) Pengumpulan kuis secara individual.

12) Pembahasan kuis.

13) Memberikan reward kepada siswa yang terbaik.

14) Guru menutup proses belajar mengajar.

\section{c. Observasi}

Observasi dilaksanakan bersamaan dengan pelaksanaan tindakan. Pada tahap ini dilakukan pemantauan jalannya proses pembelajaran yang dilaksanakan bersama guru. Yang diamati yaitu keaktifan siswa selama proses pembelajaran berlangsung. Tujuan dari observasi tersebut adalah untuk mengetahui seberapa jauh pelaksanaan tindakan yang sedang berlangsung dapat diharapkan menghasilkan perubahan yang diinginkan.

Tabel 2. Pengukuran keaktifan siswa pada siklus 1

\begin{tabular}{|c|c|c|c|}
\hline Kriteria & Skor & Persentase & Keterangan \\
\hline
\end{tabular}




\begin{tabular}{|c|c|l|l|l|}
\hline & & Sebelum & Siklus 1 & \\
\hline Sangat baik & $90-100$ & & & \\
\hline Baik & $80-89$ & & & \\
\hline Cukup & $65-79$ & & & \\
\hline Kurang & $55-64$ & & & \\
\hline Sangat kurang & $\leq 54$ & & & \\
\hline
\end{tabular}

Tabel 3. Pengukuran keaktifan siswa pada siklus 2

\begin{tabular}{|c|c|c|c|c|}
\hline \multirow{2}{*}{ Kriteria } & \multirow{2}{*}{ Skor } & \multicolumn{2}{|c|}{ Persentase } & \multirow{2}{*}{ Keterangan } \\
\cline { 3 - 4 } & & Siklus 1 & Siklus 2 & \\
\hline Sangat baik & $90-100$ & & & \\
\hline Baik & $80-89$ & & & \\
\hline Cukup & $65-79$ & & & \\
\hline Kurang & $55-64$ & & & \\
\hline Sangat kurang & $\leq 54$ & & & \\
\hline
\end{tabular}

d. Refleksi

Hasil observasi dijadikan sebagai acuan dalam mengambil solusi untuk perbaikan dan untuk penyusunan rencana tindakan pada siklus berikutnya.

\section{Siklus 2}

Siklus 2 dilaksanakan berdasarkan hasil refleksi dari siklus 1. Proses pada siklus 2 sama dengan proses pada siklus 1 . Pada siklus ini dilakukan perbaikan dari kekurangan yang terjadi dari siklus 1.

Rancangan penelitian tindakan dapat dilihat pada gambar berikut:

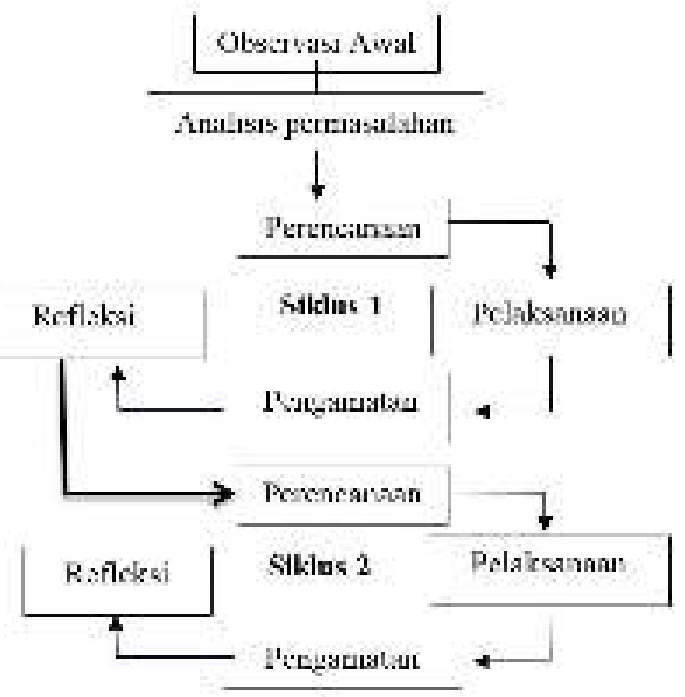

Gambar 1. Siklus penelitian tindakan kelas

\section{HASIL PENELITIAN DAN PEMBAHASAN Hasil Penelitian Siklus 1 Hasil penelitian}


Hasil tes siklus 1 selengkapnya dapat dilihat pada lampiran 5 dan terangkum dalam tabel berikut.

Tabel 4. Data hasil tes siklus 1 siswa kelas X.MIA 1

\begin{tabular}{|l|l|c|}
\hline No & \multicolumn{1}{|c|}{ Pencapaian } & $\begin{array}{c}\text { Hasil } \\
\text { tes }\end{array}$ \\
\hline 1. & Nilai Tertinggi & $\mathbf{9 0}$ \\
\hline 2. & Nilai terendah & $\mathbf{6 0}$ \\
\hline 3. & Nilai rata-rata & $\mathbf{7 8 , 3 3}$ \\
\hline 4. & Jumlah siswa yang tuntas & $\mathbf{1 9}$ \\
\hline 5. & Jumlah siswa kelas X.MIA 1 & $\mathbf{3 0}$ \\
\hline 6. & $\begin{array}{l}\text { Persentase tuntas belajar } \\
\text { secara klasikal }\end{array}$ & $\mathbf{6 3 , 3 3}$ \\
\hline
\end{tabular}

Berdasarkan tabel di atas dapat diketahui bahwa nilai rata-rata siswa pada siklus 1 mencapai 78,33 dengan ketuntasan belajar siswa secara klasikal 63,33\%. Penyajian materi dengan menggunakan model pembelajaran kooperatif TPS dapat meningkatkan prestasi belajar. Hal ini terbukti pada siklus 1 nilai hasil tes berkisar antara $60-$ 90 dengan nilai rata-rata kelas 78,33 . Terjadi peningkatan nilai rata-rata siswa sebesar 5,83 dibandingkan sebelum diterapkannya model pembelajaran TPS. Sebanyak 19 siswa mendapatkan nilai di atas 76 .

\section{Observasi}

Observasi digunakan untuk penilaian aktivitas siswa selama proses pembelajaran. Berikut ini adalah hasil observasi penerapan model pembelajaran kooperatif TPS :

Tabel 5. Data hasil pengukuran keaktifan siswa pada siklus 1

\begin{tabular}{|c|c|c|c|c|}
\hline \multirow[b]{2}{*}{ Kriteria } & \multirow[b]{2}{*}{ Skor } & \multicolumn{2}{|c|}{ Persentase } & \multirow{2}{*}{$\begin{array}{c}\text { Keteran } \\
\text { gan }\end{array}$} \\
\hline & & $\begin{array}{c}\text { Sebel } \\
\text { um }\end{array}$ & $\begin{array}{c}\text { Siklus } \\
1\end{array}$ & \\
\hline $\begin{array}{l}\text { Sangat baik } \\
\text { (A) }\end{array}$ & $\begin{array}{l}90- \\
100\end{array}$ & 0 & 13,33 & \\
\hline Baik (B) & $\begin{array}{c}80- \\
89\end{array}$ & 16,67 & 50,00 & \\
\hline Cukup (C) & $\begin{array}{c}65- \\
79\end{array}$ & 50,00 & 36,67 & \\
\hline Kurang (D) & $\begin{array}{c}55- \\
64 \\
\end{array}$ & 23,33 & 0 & \\
\hline $\begin{array}{l}\text { Sangat } \\
\text { kurang (E) }\end{array}$ & $\leq 54$ & 10,00 & 0 & \\
\hline
\end{tabular}

mengalami peningkatan persentase indikatornya. Sebelum menerapkan model pembelajaran kooperatif TPS untuk indikator
Sangat Baik ( A ) persentasenya 0\%, untuk indikator Baik ( B ) persentasenya 16,67\%, untuk indikator Cukup ( C ) persentasenya 50\%, untuk indikator Kurang ( D ) persentasenya 23,33\% dan untuk indikator Sangat Kurang ( E ) persentasenya $10,00 \%$. Setelah menerapkan model pembelajaran pembelajaran kooperatif TPS pada siklus 1 diperoleh hasil, untuk indikator Sangat Baik ( A ) persentasenya 13,33\%, untuk indikator Baik ( B ) persentasenya $50,00 \%$, untuk indikator Cukup ( C ) persentasenya 36,67\%, untuk indikator Kurang ( D ) persentasenya 0\% dan untuk indikator Sangat Kurang ( E ) persentasenya $0 \%$.

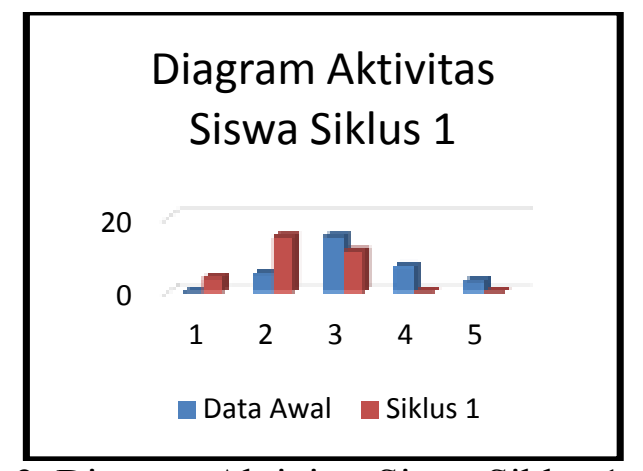

Gambar 2. Diagram Aktivitas Siswa Siklus 1

Hasil analisis penilaian afektif siklus 1 ini menunjukkan adanya respon yang sangat baik dari siswa terhadap proses pembelajaran yang dilihat dari respon siswa yang sangat baik pada siklus 1 sebesar 33, siswa yang mempunyai respon baik sebesar $60 \%$ dan hanya $7 \%$ siswa yang mempunyai respon cukup dan ditunjukkan pada gambar 3 .

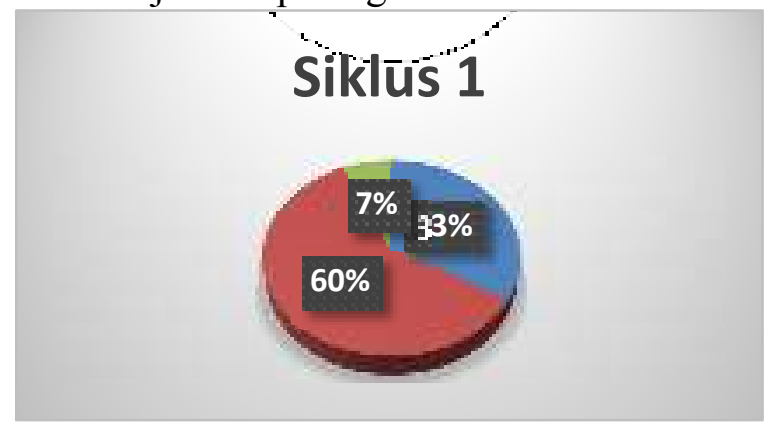

Gambar 3. Diagram peningkatan nilai afektif siswa siklus 1

\section{Refleksi}

Berdasarkan data tes ketuntasan belajar pada siklus 1 belum tercapai, ketuntasan belajar yang diperoleh pada siklus 1 adalah $63,33 \%$ dengan rata-rata nilai 78,33 . Oleh karena itu, 
peneliti perlu melanjutkan ke siklus 2 untuk memperoleh nilai hasil belajar yang diinginkan. Selain itu, pada siklus 1 diperoleh hasil tingkat keaktifan siswa meningkatkan dari sebelum menggunakan model pembelajaran kooperatif TPS.

\section{Hasil Penelitian Siklus 2}

Pada akhir siklus 2 dilaksanakan tes untuk memperoleh data hasil belajar siswa selengkapnya pada lampiran 12 dan terangkum pada tabel 8 berikut:

Tabel 6. Data hasil tes siklus 2 siswa kelas $X$ MIA 1

\begin{tabular}{|c|l|c|}
\hline No & Pencapaian & Hasil tes \\
\hline 1. & Nilai Tertinggi & $\mathbf{9 5}$ \\
\hline 2. & Nilai terendah & $\mathbf{7 0}$ \\
\hline 3. & Nilai rata-rata & $\mathbf{8 2 , 5 0}$ \\
\hline 4. & Jumlah siswa yang tuntas & $\mathbf{2 6}$ \\
\hline 5. & Jumlah siswa kelas X MIA 1 & $\mathbf{3 0}$ \\
\hline
\end{tabular}

\begin{tabular}{|l|l|c|}
\hline 6. & $\begin{array}{l}\text { Persentase tuntas belajar } \\
\text { secara klasikal }\end{array}$ & $\mathbf{8 6 , 6 7}$ \\
\hline
\end{tabular}

Berdasarkan tabel di atas diketahui bahwa ketuntasan belajar siswa mengalami peningkatan menjadi $86,67 \%$ dengan rata-rata 82,50 . Hasil ini sudah memenuhi indikator kerja penelitian.

\section{Observasi}

Hasil observasi pada siklus 2 menunjukkan siswa lebih terlibat aktif dalam proses pembelajaran dan diskusi kelompok. Tidak hanya siswa yang pandai yang berani mempresentasikan hasil diskusi melainkan tetapi siswa yang lainnya juga. Observasi digunakan untuk penilaian aktivitas siswa selama proses pembelajaran. Berikut ini adalah hasil observasi penerapan model pembelajaran kooperatif TPS :

Tabel 7. Data hasil pengukuran keaktifan siswa pada siklus 2

\begin{tabular}{|c|c|c|c|c|}
\hline \multirow{2}{*}{ Kriteria } & \multirow{2}{*}{ Skor } & \multicolumn{2}{|c|}{ Persentase } & \multirow{2}{*}{ Keterangan } \\
\hline & & Sebelum & Siklus 2 & \\
\hline Sangat baik (A) & $90-100$ & 13,33 & 33,33 & \\
\hline Baik (B) & $80-89$ & 50,00 & 56,67 & \\
\hline Cukup (C) & $65-79$ & 36,67 & 10,00 & \\
\hline Kurang (D) & $55-64$ & 0 & 0 & \\
\hline Sangat kurang (E) & $\leq 54$ & 0 & 0 & \\
\hline
\end{tabular}

Dari data tabel 9 setelah menerapkan model pembelajaran kooperatif TPS pada siklus 1 diperoleh hasil, untuk indikator Sangat Baik ( A ) persentasenya $13,33 \%$, untuk indikator Baik ( B ) persentasenya 50,00\%, untuk indikator Cukup ( C ) persentasenya 36,67\%, untuk indikator Kurang ( D ) persentasenya $0 \%$ dan untuk indikator Sangat Kurang ( E ) persentasenya $0 \%$. Untuk siklus 2 diperoleh hasil, indikator Sangat Baik ( A ) persentasenya $33,33 \%$, untuk indikator Baik ( $\mathrm{B})$ persentasenya $56,67 \%$, untuk indikator Cukup ( C ) persentasenya $10,00 \%$, untuk indikator Kurang ( D ) persentasenya $0 \%$ dan untuk indikator Sangat Kurang ( E ) persentasenya $0 \%$.

Berdasarkan hasil analisis penilaian afektif siklus 2 menunjukkan adanya respon yang sangat baik dari siswa terhadap proses pembelajaran yang dilihat dari respon siswa dengan indikator sangat baik pada siklus 2 sebesar $64 \%$, siswa yang mempunyai respon baik sebesar 33\% dan hanya 3\% siswa yang mempunyai respon cukup dan ditunjukkan pada gambar 5.

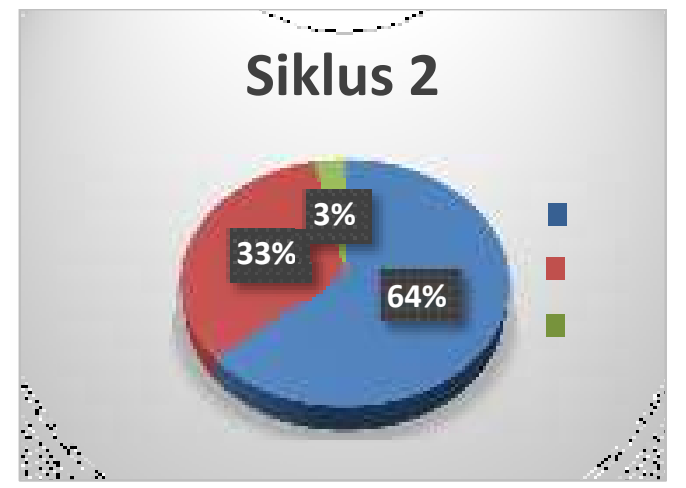

Gambar 5. Diagram peningkatan nilai afektif siswa siklus 2

\section{Refleksi}

Dari data tes hasil belajar siswa pada siklus 2 diperoleh ketuntasan belajar siswa $86,67 \%$ dengan rata-rata 82,50 . Hasil ini telah memenuhi standar ketuntasan belajar. Dari data hasil belajar siswa menunjukkan adanya peningkatan minat siswa. untuk hasil observasi 
yang telah dilaksanakan dapat dilihat bahwa penerapan model pembelajaran kooperatif TPS dapat meningkatkan keaktifan siswa antara sebelum dan sesudah diterapkannya model pembelajaran kooperatif mencapai $100 \%$.

Hal ini berarti semua aspek keaktifan siswa telah mencapai indikator kinerja ketercapaian tindakan. Jika ditinjau dari ketercapaian indikator kinerja bertujuan dari segi hasil belajar 26 siswa berhasil mendapatkan nilai di atas 76 , dengan kata lain $85 \%$ siswa telah mencapai indikator kinerja yang direncanakan sebesar 75\%. Setelah menganalisis dan mengolah data hasil belajar dan observasi serta refleksi siklus 2 diperoleh kesimpulan bahawa kedua indikator kinerja ketercapaian tujuan penelitian, baik dilihat dari variabel keaktifan maupun variabel hasil belajar siswa terpenuhi. Oleh karena itu, dapat disimpulkan bahwa penelitian tindakan kelas telah berhasil sehingga tidak perlu dilakukan tindakan perbaikan siklus berikutnya.

\section{Pembahasan}

Hasil pelaksanaan tindakan pada siklus 1 dan 2 menunjukkan bahwa penerapan model pembelajaran kooperatif TPS (Think-PairShare) dapat meningkatkan hasil belajar belajar siswa pada pokok bahasan reaksi redoks. Peningkatan Hasil belajar dan ketuntasan belajar siswa dapat dilihat pada grafik sebagai berikut:

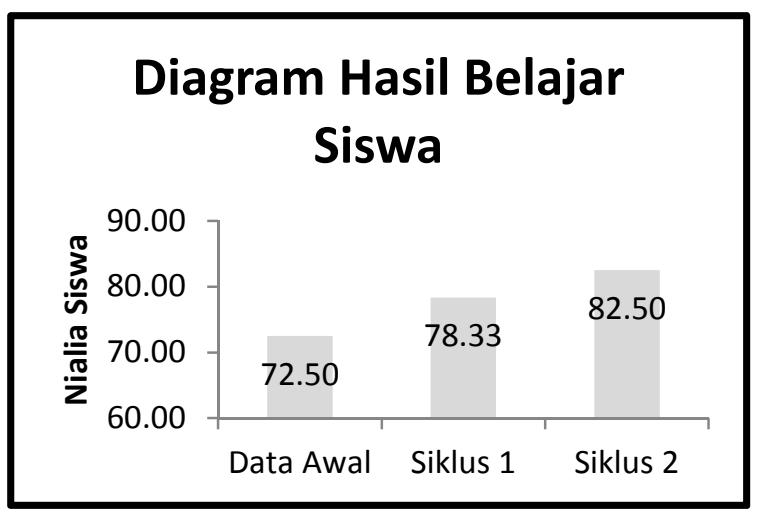

Gambar 6. Diagram peningkatan hasil belajar siswa

\section{Diagram Ketuntasan Belajar Siswa}

Gambar 7. Diagram ketuntasan belajar siswa

Dari diagram tersebut memberikan informasi bahwa pada nilai rata-rata kelas mengalami peningkatan. Sebelum adanya penerapan model pembelajaran kooperatif TPS nilai rata-rata kelas siswa adalah 72,50 tetapi setelah penerapan model pembelajaran kooperatif TPS nilai rata-rata kelas siswa menjadi 78,33 pada siklus 1 dan 82,50 pada siklus 2. Terjadi peningkatan nilai rata-rata siswa dibandingkan sebelum diterapkannya model pembelajaran TPS. Sebanyak 19 siswa $(63,63 \%)$ mendapatkan nilai di atas 76 dan pada siklus 2 nilai rata-rata kelas 82,50 sehingga terjadi peningkatan dibanding siklus 1 . Sebanyak 26 siswa $(86,67 \%)$ sudah mencapai nilai di atas 76 dari $75 \%$ target yang direncanakan. Hasil penelitian ini mendukung hasil penelitian yang sebelumnya yang dilaksanakan oleh Tri Yudi Waluyo Pambudi yang berjudul "Pengaruh Model Pembelajaran Kooperatif Tps (Think Pair Share) Melalui Snowball Throwing Terhadap Hasil Belajar Siswa Kelas X Pada Kompetensi Yang Berkaitan Dengan Redoks". Penelitian tersebut menyimpulkan bahwa rata-rata hasil belajar siswa meningkat yaitu daya serap siswa $81,00 \%$, ketuntasan belajar siswa 90,48\% .

Aktivitas siswa meningkat rata-rata dengan kategori Sangat Baik ( A ) persentasenya $13,33 \%$, untuk kategori Baik ( B ) persentasenya $50,00 \%$, untuk kategori Cukup ( C ) persentasenya 36,67\%, untuk kategori Kurang ( D ) persentasenya $0 \%$ dan untuk kategori Sangat Kurang ( E ) persentasenya $0 \%$. Sedangkan untuk siklus 2 diperoleh hasil, kategori Sangat Baik ( A ) persentasenya 33,33\%, untuk kategori Baik ( B ) persentasenya $56,67 \%$, untuk kategori Cukup ( C ) persentasenya $10,00 \%$, untuk kategori Kurang ( D ) persentasenya $0 \%$ dan untuk kategori Sangat Kurang ( E ) persentasenya $0 \%$. Dari 2 siklus terjadi peningkatan aktivitas siswa dengan menerapkan model pembelajaran 
kooperatif tipe TPS meningkat secara signifikan.

Penerapan model pembelajaran kooperatif Think Pair Share (TPS) pada siklus 1 berjalan cukup lancar, siswa pun dapat ikut berpartisipasi di dalam KBM meskipun ada beberapa siswa yang ramai dan kurang memperhatikan. Berdasarkan hasil pengamatan terhadap proses belajar mengajar pada siklus 1 masih terdapat kekurangan yaitu siswa belum bisa bekerja sama secara optimal dengan teman sebangkunya. Selain itu, siswa juga belum berani untuk mengemukakan pendapatnya di depan teman-teman dan guru. Hasil belajar siswa pada siklus 1 juga masih rendah meskipun sudah ada beberapa siswa yang mendapatkan nilai di atas 76 . Peneliti mencari solusi dengan merencanakan siklus 2. Materi pada siklus 2 adalah Oksidator dan Reduktor dalam Reaksi Redoks. Berdasarkan hasil pengamatan terhadap proses pembelajaran pada siklus 2 siswa terlihat semakin aktif dan kelemahan pada siklus 1 sudah teratasi pada siklus 2. Siswa yang sebelumnya masih terlihat malu-malu untuk mengemukakan pendapat sekarang mulai berani bertanya dan memberikan pendapatnya kepada teman ataupun guru.

Berdasarkan uraian di atas dapat disimpulkan bahwa Penelitian Tindakan Kelas (PTK) upaya peningkatan aktivitas dan hasil belajar pada pokok bahasan reaksi redoks melalui model pembelajaran kooperatif Think Pair Share (TPS) bagi siswa kelas X MIA 1 SMA N 2 Rambah Hilir Tahun Pelajaran 2017/2018 adalah berhasil dan dapat dipertanggungjawabkan hasilnya. Hal ini dikarenakan PTK telah dilaksanakan sesuai dengan prosedur penelitian mulai dari tahap perencanaan, pelaksanaan tindakan, observasi, dan refleksi.

\section{KESIMPULAN}

Dengan menggunakan model pembelajaran kooperatif tipe TPS dapat meningkatkan aktivitas dan hasil belajar kimia pada pokok bahasan reaksi redoks pada siswa kelas X.MIA 1 semester 2 SMA N 2 Rambah Hilir Tahun ajaran 2017/2018. Hal ini ditunjukkan adanya perubahan sikap siswa dalam pembelajaran, diantaranya adalah interaksi dan kerja sama antar siswa semakin baik, siswa semakin mempunyai keberanian untuk mengemukakan ide dan pendapat di depan kelas. Pusat pembelajaran tidak lagi pada guru. Siswa dituntut untuk aktif mencari informasi serta harus dapat saling bertukar pikiran.

Peningkatan ini terlihat dari nilai rata-rata yang diperoleh siswa yaitu 78,33 pada siklus 1, kemudian meningkat menjadi 82,50 pada siklus 2. Ketuntasan belajar siswa juga mengalami peningkatan pada siklus 1 adalah $63,33 \%$, kemudian pada siklus 2 meningkat menjadi $86,67 \%$. Ketuntasan belajar siswa secara klasikal sudah terpenuhi yaitu $85 \%$ dari jumlah siswa memperoleh nilai lebih besar atau sama dengan 76. Namun secara individual masih ada 4 siswa yang belum tuntas belajar. Siswa mempunyai kesempatan untuk mempelajari materi secara berulang-ulang dan kemudahan memahami materi yang disampaikan oleh teman sebaya. Siswa dituntut untuk bertukar informasi atau mengajarkan materi kepada temannya sehingga dapat meningkatkan pemahaman dan ingatan siswa pada materi yang dipelajari serta bertanggung jawab pada saat kuis.

\section{DAFTAR PUSTAKA}

A.M. Sardiman. 2011. Interaksi dan Motivasi Belajar Mengajar. Jakarta: Rajawali

Depdiknas. 2003. Pendekatan Kontekstual (Contextual Teaching and Learning). Jakarta: Depdiknas.

Djamarah, Syaiful Bahri dan Aswan Zain. 2002. Strategi Belajar Mengajar. Jakarta: Rineka Cipta

Hanafiah, Nanang \& Cucu Suhana. 2010. Konsep Strategi Pembelajaran. Bandung: Refika Aditama

Hamalik, Oemar. 2001. Perencanaan Pengajaran Berdasarkan Pendekatan Sistem. Jakarta: Bumi aksara.

Kartini,dkk. Sains KIMIA 1.Jakarta. PT Bumi Aksara

Lie, A. 2004. Cooperative Learning Mempraktekkan di Ruang-ruang Kelas. Jakarta: PT Grasindo

Mulyasa, E. 2004. Kurikulum Berbasis Kompetensi. Bandung: Remaja Rosdakarya. 
Nasution, S. 2003. Berbagai Pendekatan dalam Proses Belajar dan Mengajar. Bandung: Bumi Aksara

Pambudi,TY. 2013. Pengaruh model pembelajaran kooperatif tps (think pair share) melalui snowball throwing terhadap hasil belajar siswa kelas $\mathrm{x}$ pada kompetensi yang berkaitan dengan redoks. Skripsi. Semarang : UNNES

Slameto. 2003. Belajar dan Faktor-faktor yang Mempengaruhinya. Jakarta: Rineka Cipta

Slavin, Robert E. 1995. Cooperatif Learning.

Boston London, Allyn and Bacon

Sudjana, Nana. 2001. Penilaian Hasil Proses Belajar Mengajar. Bandung: Remaja Rosdakarya

Utami B, dkk. 2009. Kimia untuk SMA/MA kelas $X$ program ilmu alam. Jakarta: Pusat perbukuan. Departemen Pendidikan Nasional. 